\title{
Efektivitas hyaluronic acid $0,1 \%$ terhadap penyembuhan luka trauma akibat piranti ortodontik cekat

\author{
Effectivity of $0.1 \%$ hyaluronic acid toward to healing of trauma injury due to fixed \\ orthodontics
}

\author{
Hanna Silvia Debora, Nada Ismah, Benny Mulyono Soegiharto \\ Departemen Ortodontik \\ Fakultas Kedokteran Gigi, Universitas Indonesia \\ Jakarta, Indonesia
}

\section{ABSTRACT}

Treatment with a fixed orthodontic aims to improve malocclusion and enhance the aesthetic. Traumatic injury to the mucosa of the mouth is one of the risks that often occur and can be addressed among others by using mouthwash that contains hyaluronic acid. This study aimed to determine the effectiveness of $0.1 \%$ hyaluronic acid on wound healing caused by trauma of fixed rthodontic appliance in terms of size wound, redness and pain. Twenty two patients who had a traumatic injury caused by fixed appliance on buccal or labial mucosa were divided into 2 groups: K1, was instructed to rinse $10 \mathrm{ml}$ solution containing $0.1 \%$ hyaluronic acid for 2 minutes after brushing teeth, 2 times a day for 4 days; K2, used the K1's instruction but using a placebo solution. Examination of size are used caliper and reddish wounds are used index measuring wound redness performed before and after treatment, and pain measurement used questionnaires. Based on the statistical analysis of t-test, the percentage of size changes and redness traumatic injury were more significant in $K 1$ than in $K 2(p<0.05)$. While the pain of traumatic changes in $K 1$ than in $K 2$ were not significant ( $p>0.05$ ). The use of mouthwash containing $0.1 \%$ hyaluronic acid was concluded proved effective to accelerate the wound healing process, but does not prove effective reducing pain caused by traumatic injury due to fixed orthodontic appliance.

Keywords: $0.1 \%$ hyaluronic acid, wound healing, fixed orthodontic appliance

\begin{abstract}
ABSTRAK
Perawatan ortodontik dengan piranti cekat bertujuan memperbaiki maloklusi dan meningkatkan estetik. Luka trauma pada mukosa mulut merupakan salah satu risiko yang sering terjadi, antara lain dapat diatasi dengan menggunakan obat kumur yang mengandung hyaluronic acid. Penelitian ini bertujuan untuk mengetahui efektivitas hyaluronic acid $0,1 \%$ terhadap penyembuhan luka trauma akibat piranti ortodontik cekat ditinjau dari perubahan ukuran luka, kemerahan luka dan rasa nyeri. Tiga puluh dua penderita luka trauma akibat piranti cekat pada mukosa bukal atau labial dibagi menjadi 2 kelompok: K1, diinstruksikan untuk berkumur $10 \mathrm{ml}$ larutan yang mengandung hyaluronic acid $0,1 \%$ selama 2 menit setelah menyikat gigi, 2 kali sehari selama 4 hari; K2, dengan instruksi yang sama dengan $\mathrm{K} 1$, namun menggunakan larutan plasebo. Pemeriksaan ukuran digunakan kaliper dan kemerahan luka digunakan indeks pengukur kemerahan, dilakukan sebelum dan sesudah perlakuan. Pengukuran rasa nyeri digunakan kuesioner. Berdasarkan analisis uji-t, persentase perubahan besar dan kemerahan luka trauma pada K1 lebih signifikan dibandingkan pada K2 $(\mathrm{p}<0,05)$. Sedangkan perubahan rasa nyeri luka trauma pada K1 tidak signifikan dibandingkan K2 (p>0,05). Disimpulkan bahwa penggunakan obat kumur yang mengandung hyaluronic acid $0,1 \%$ terbukti efektif mempercepat proses penyembuhan luka trauma, akan tetapi tidak terbukti efektif menurunkan rasa nyeri luka trauma akibat piranti cekat.
\end{abstract}

Kata kunci: hyaluronic acid $0,1 \%$, penyembuhan luka, piranti ortodontik cekat

Koresponden: Nada Ismah, Departemen Ortodontik, Fakultas Kedokteran Gigi, Universitas Indonesia, Jl. Salemba Raya No.4, Jakarta 10430, Gedung B, Lt. 2. Indonesia, E-mail: nadalukman@yahoo.com 